\title{
Kalsifikasi Tulang dan Proses Regenerasi Ekor Ikan Wader (Rasbora lateristriata)
}

\section{Geterudis Kerans ${ }^{1}$}

${ }^{1}$ Program Studi Pendidikan Ilmu Pengetahuan Alam, Sekolah Tinggi Keguruan dan Ilmu Pendidikan, Weetebula.

*Corresponding Author: Geterudis Kerans; Sekolah Tinggi Keguruan dan Ilmu Pendidikan, Weetebula Email:

Geterudiskerans@yahoo.com

\begin{abstract}
Skeleton merupakan alat gerak pasif yang berfungsi sebagai penopang tubuh dan memberi bentuk tubuh. Morfologi makhluk hidup bagian luar salah satunya dibentuk oleh bentuk skeleton, sehingga dapat dibedakan antara spesies yang satu dengan yang lain. Morfologi atau kenampakan bentuk skeleton berbeda dalam setiap perkembangan, karena mengalami diferensiasi.Pada ikan genus Rasbora, perkembangan skeleton dan perbedaan skeletonnya masih sangat sedikit dikaji, terlebih lagi pada spesies $R$. lateristriata.Kekhasan lain yang ingin diamati adalah bagaimana ikan ini mampu beregenerasi. Hampir semua organisme hidup mempunyai kemampuan beregenerasi. Kemampuan regenerasi masing-masing organisme tidak sama. Penelitian ini bertujuan untuk mengamati proses kalsifikasi tulang pada Ikan Wader (Rasboralateristriata) dan mengidentifikasi regenerasi ekor ikan wader (Rasbora lateristriata). Hasilnya menunjukan bahwa ikan wader telah mengalami proses osifikasi atau penulangan sehingga pada hasil pengamatan dilihat hampir seluruh tulang ikan wader terwarnai merah yang berarti tersusun atas tulang keras. Sedangkan bagian kecil pada bagian ekor ikan terdapat warna biru yang menunjukan bahwa bagian tersebut tersusun atas tulang rawan.Ekor ikan wader yang telah dipotong utuh siripnya kembali tumbuh mulai hari ke 6 secara perlahan hingga hari ke 21 telah kembali seperti semula.Pada pengamatan ini menunjukan bahwa pada bagian ekor ikan wader terdapatstem sel sehingga ekor ikan dapat mengalamiregenerasi.
\end{abstract}

Keywords:Kalsifikasi, Regenerasi, Rasbora lateristriata.

Dalam dunia ilmu biologi, ikan memiliki daya tarik tersendiri untuk dipelajari, baik dari anatomi dan morfologinya, fisiologi bahkan struktur histologinya. Salah satu jenis ikan endemic yang saat ini dipelajari adalah ikan wader. Ikan wader Rasbora Leteristriata merupakan ikan air tawar yang biasa hidup di sungai-sungai yang airnya jernih. Menurut Rahmadiyanto (1994), Ikan air tawar yang biasa hidup di sungai-sungai, sawahsawah, dan perairan yang airnya jernih biasanya sulit bisa bertahan hidup pada lingkungan yang 
kurang mendukung, misal air yang keruh, derasnya aliran air, goncangan dan suhu yang terlalu tinggi atau rendah.

Skeleton merupakan alat gerak pasif yang berfungsi sebagai penopang tubuh dan memberi bentuk tubuh. Morfologi makhluk hidup bagian luar salah satunya dibentuk oleh bentuk skeleton, sehingga dapat dibedakan antara spesies yang satu dengan yang lain. Morfologi atau kenampakan bentuk skeleton berbeda dalam setiap perkembangan, karena mengalami diferensiasi.

Diferensiasi skeleton pada setiap jenis ikan berbeda-beda, tergantung dari banyak faktor salah satunya adalah umur. Proses pembentukan skeleton pada ikan dapat terjadi setelah ikan menetas dan sebelum menetas. Penelitian sebelumnya menyebutkan bahwa pembentukan cranium pada ikan Salmo trutta (De Beer, 1937 dalam Saka et al., 2008) dan Barbus barbus (Vandewalle et al., 1992 dalam Saka et al., 2008 dimulai sebelum menetas. Pada ikan Clarias gariepinus (Surlemont \& Vandewalle, 1991 dalam Saka et al., 2008), Dentex dentex (Koumoundouros et al., 2000 dalam Saka et al., 2008) dan Sparus aurata, cranium terbentuk setelah ikan menetas dan osifikasi ketika ikan mencapai panjang total (TL) 9,35 mm (Saka et al., 2008).

Pada ikan genus Rasbora, perkembangan skeleton dan perbedaan skeletonnya masih sangat sedikit dikaji, terlebih lagi pada spesies $R$. lateristriata. Penelitian mengenai ikan jenis ini dan kerabatnya belum banyak dilakukan, bahkan perkembangan skeleton belum terdokumentasi. Penelitian ini perlu dilakukan untuk memberikan data base mengenai proses osifikasi pada skeleton $R$. lateristriata sehingga bisa digunakan untuk data acuan pada penelitian lanjutan.

Kekhasan lain yang ingin diamati adalah bagaimana ikan ini mampu beregenerasi. Hampir semua organisme hidup mempunyai kemampuan beregenerasi. Kemampuan regenerasi masingmasing organisme tidak sama. Proses regenerasi dimulai dengan pembentukan tudung ektodermal apical. Proses penyembuhan luka juga termasuk dalam regenerasi. Regenerasi tidak hanya terjadi pada ikan, tetapi bisa juga pada kecoa, cicak dan manusia. Berdasarkan latar belakang di atas maka, pada Penelitian kali ini, dilakukan beberapa pengmatan pada ikan wader yaitu pengamatan bentuk dan susunan tulang pada ikan wader $\mathrm{R}$. lateristriata, dan regenerasi Ekor ikan wader R. lateristriata.

Berdasarkan penjabaran di atas, tujuan dari penelitian ini adalah mengamati proses kalsifikasi tulang pada Ikan Wader (Rasboralateristriata)dan mengidentifikasi regenerasi ekor ikan wader (Rasbora lateristriata)

\section{Metode}

Alat dan bahan

Pengamatan Kalsifikasi tulang: Ikan wader, Alkohol 96\%, Larutan KOH 0,25 \% dan 0,125\%, Larutan gliserin, Pewarna ARAB, akuades, Botol flakon, Kamera, Alat bedah, dan kertas label

Pengamatan Regenerasi ekor: Ikan wader 15 ekor, Pisau potong/gunting, Tissue, betadine, Alkohol, Es, Metilen blue, wadah, Akuarium, Aerator, Penggaris, Petri disk, Kamera, mikroskop.

\section{Cara Kerja}

Pengamatan kalsifikasi tulang: ikan wader yang masih hidup diambil dan dianastesi dengan direndam dalam suhu dingin (menggunakan es batu). Selanjutnya ikan wader difiksasi menggunakan alcohol 96\% selama 3 hari kemudian direndam dalam pewarna Alizzarin red dan Alcian blue selama 3 hari hingga terwarnai sempurna. Sampel kemudian dicuci dengan aquades kemudian direndam dalam $\mathrm{KOH} 0,25 \%$ kemudian $\mathrm{KOH}$ $0.125 \%$ hingga terlihat transparan. Setelah itu sampel disimpan dalam rendaman larutan gliserin :KOH $0,125 \%$ sebanyak $1: 1$. Hasilnya difoto dan diamati hasil warna yang tampak pada masingmasing bagian tulang.

Pengamatan regenerasi ekor:5 ekor ikan wader di bius dengan cara direndam di dalam petri disk berisi es batu kemudian semua ikan dipotong 
bagian sirip kaudalnya dengan full cutting. Selanjutnya bagian yang dipotong dibersihkan dengan alcohol 70\% kemudian dioleskan betadine. Pengamatan regenerasi dilakukan setiap 2 hari.

\section{Hasil dan Pembahasan}

\section{Kalsifikasi Tulang Ikan Wader (Rasbora Lateristriata)}

Teknik pewarnaan Alcian Blue dan Alizarin Red digunakan untuk mengetahui susunan tulang rawan dan tulang keras berdasarkan perbedaan penyerapan terhadap zat warna. Tujuan penggunaan pewarnaan ganda ini karena tulang fetus tersusun dari beberapa jenis tulang yaitu tulang rawan dan tulang keras. Masing-masing akan memiliki afinitas yang berbeda dalam penyerapan zat warna sehingga akan terlihat perbedaan jenis tulang tersebut. Ruas tulang yang terwarnai Alizarin Red (merah) adalah tulang keras, sedangkan ruas tulang yang terwarnai Alcian Blue (biru) adalah tulang rawan.

Pada Penelitian ini ada beberapa larutan yang digunakan yaitu Alkohol 96\% yang digunakan untuk mengfiksasi atau menghilangkan kandungan air di dalam jaringan ikan wader baru selanjutnya diwarnai. Selain alcohol juga digunakan larutan $\mathrm{KOH}$. Ikan wader yang telah diwarnai akan dicuci dengan aquades baru selanjutnya direndam dalam $\mathrm{KOH}$. Perendaman dengan $\mathrm{KOH}$ bertujuan untuk membuat otot atau jaringan selain jaringan tulang terlihat transparan. Akan tetapi, pada Penelitian ini, karena perendaman yang dilakukan praktikan terlalu lama mengakibatkan jaringan otot ikan wader menjadi lunak dan hancur.

Dari Penelitian yang telah dilakukan dapat kita amati bersama hasil pewarnaan tulang ikan wader dan bagian-bagian yang terwarnai dengan ciri khas tulangnya. Hasil dapat kita lihat pada gambar di bawah ini:

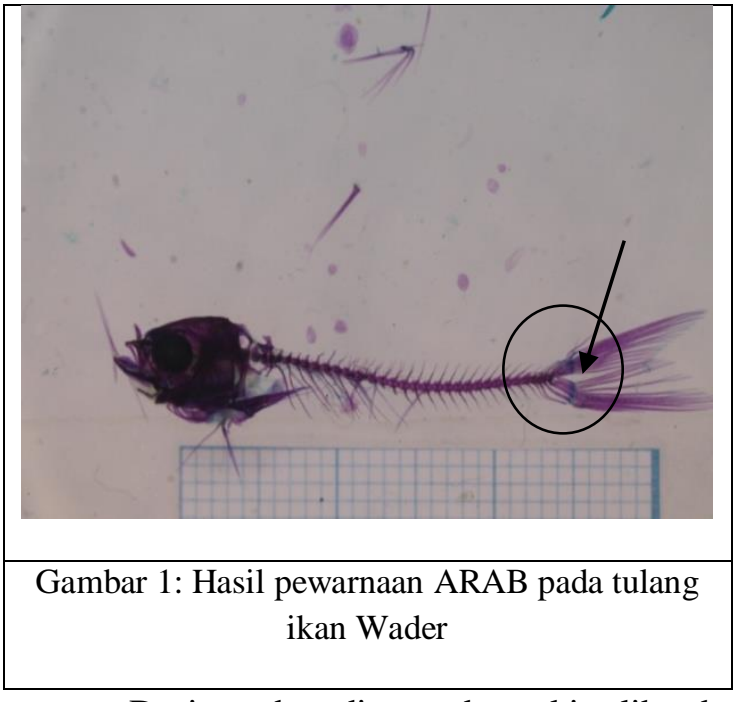

Dari gambar di atas dapat kita lihat bahwa hampir semua bagian tulang ikan wader terwarnai merah dan hanya pada bagian kecil di daerah ekor yang ditunjuk anak panah terlihat berwarna biru. Hal ini menunjukan bahwa tulang ikan wader telah mengalami osifikasi atau proses penulangan yang sempurna sehingga hampir seluruh tubuh ikan wader telah ditopang oleh tulang keras. Bagian kecil yang terlihat berwarna biru menunjukan bahwa daerah itu masih terdapat tulang rawan.

\section{Regenerasi Ekor Ikan Wader (Rasbora Lateristriata)}

Hampir semua organisme hidup mempunyai kemampuan beregenerasi. Kemampuan regenerasi masing-masing organisme tidak sama. Proses regenerasi dimulai dengan pembentukan tudung ektodermal apical. Proses penyembuhan luka juga termasuk dalam regenerasi. Dalam penelitian ini, ekor ikan wader dipotong habis dan dalam pengamatan selama setiap 2 hari dapat dilihat bahwa pada hari kedua, ekor masih belum menunjukan perubahan sampai pada hari keempat juga belum ada perubahan namun pada hari ke 6 hingga hari ke 21 regenerasi ekor terus berlangsung hingga ekor kembali terbentuk seperti semula. Hal ini dapat di lihat pada gambar di bawah ini: 


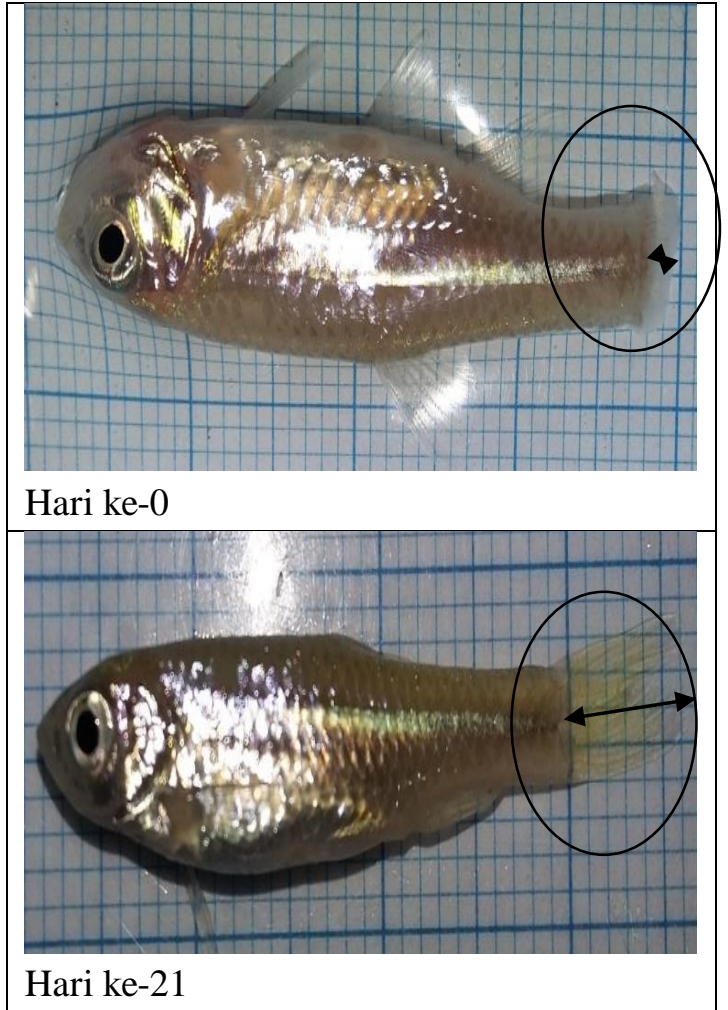

Pada Gambar di atas terlihat ekor yang telah dipotong utuh kembali tumbuh hingga hari ke-21, hal ini menunjukkan adanya jaringan stem sel pada bagian kaudal ikan tersebut sehingga terjadinya regenerasi. Menurut Kimbal (1993), regenerasi terjadi melalui beberapa tahapan, yaitu:

a. Luka akan tertutup oleh darah yang mengalir, lalu membeku membentuk scab yang bersifat sebagai pelindung.

b. Sel epitel bergerak secara amoeboid menyebar di bawah permukaan luka, di bawah scab. Proses ini membutuhkan waktu selama dua hari, dimana pada saat itu luka telah tertutup oleh kulit.

c. Diferensiasi sel-sel jaringan sekitar luka, sehingga menjadi bersifat muda kembali dan pluripotent untuk membentuk berbagai jenis jaringan baru. Matriks tulang dan tulang rawan akan melarut, sel-selnya lepas tersebar di bawah epitel. Serat jaringan ikat juga berdisintegrasi dan semua sel-selnya mengalami diferensiasi. Sehingga dapat dibedakan antara sel tulang, tulang rawan, dan jaringan ikat. Setelah itu sel-sel otot akan berdiferensiasi, serat miofibril hilang, inti membesar dan sitoplasma menyempit.

d. Pembentukan kuncup regenerasi (blastema) pada permukaan bekas luka. Pada saat ini scab mungkin sudah terlepas. Blastema berasal dari penimbunan sel-sel diferensiasi atau sel-sel satelit pengembara yang ada dalam jaringan, terutama di dinding kapiler darah. Pada saatnya nanti, sel-sel pengembara akan berproliferasi membentuk blastema.

e. Proliferasi sel-sel berdiferensiasi secara mitosis, yang terjadi secara serentak dengan proses dediferensiasi dan memuncak pada waktu blastema mempunyai besar yang maksimal dan tidak membesar lagi.

f. Rediferensiasi sel-sel dediferensiasi, serentak dengan berhentinya proliferasi sel-sel blastema tersebut. Sel-sel yang berasal dari parenkim dapat menumbuhkan alat derifat mesodermal, jaringan saraf dan saluran pencernaan. Sehingga bagian yang dipotong akan tumbuh lagi dengan struktur anatomis dan histologis yang serupa dengan asalnya.

Selain gambar diatas juga dapat kita lihat bagaimana proses regenerasi ekor ikan wader dan ikan lele dari hari ke 4 sampai hari ke 21 dengan grafik di bawah ini:

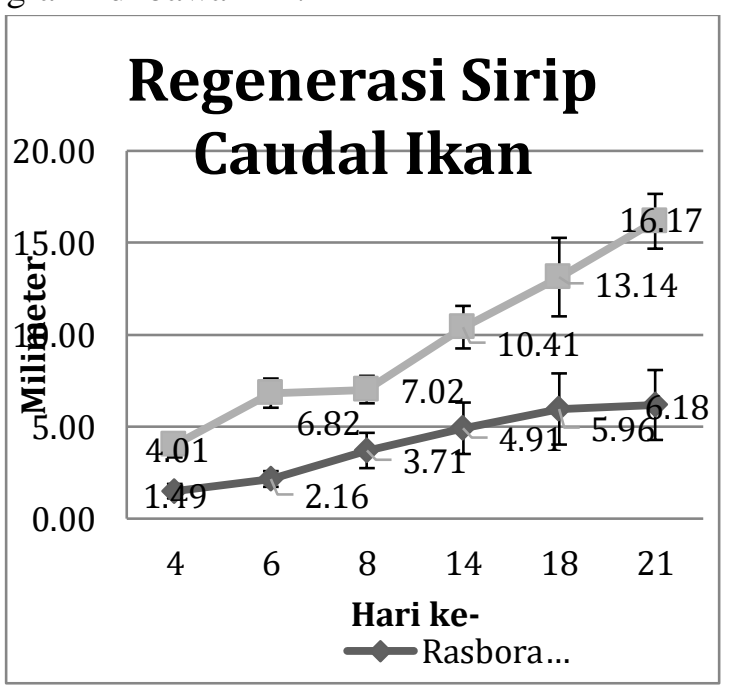

Grafik di atas menunjukan bahwa proses regenerasi ekor ikan wader (garis biru) dan regenerasi ekor ikan lele (garis orange) mengalami 
regenerasi mulai pada hari ke-6 dan terus mengalami regenerasi hingga hari ke 21. Proses regenerasi ikan lele dapat terlihat sangat cepat.

Regenerasi merupakan Kemampuan organisme mengganti bagian-bagian tubuh yang hilang baik karena luka, sobek, proses autotomi. Kemampuan regenerasi pada Avertebrata jauh lebih cepat dari pada Vertebrata. Pada Avertebrata.paling tinggi pada Hydra dan Planaria sedangkan pada vertebrata kemampuan paling tinggi pada hewan muda atau hewan-hewan yang tingkat diferensiasinya rendah pada keadaan dewasa Urodela memiliki kemampuan paling tinggi, Anura terbatas pada larva (ekor dan anggota badan), Reptil terbatas pada ekor (setelah autotomi/amputasi)dan Mamal terbatas pada regenerasi jaringan (penyembuhan luka).

\section{Kesimpulan}

1. Pewarnaan tulang dilakukan dengan teknik pewarnaan ARAB (alizarin red dan alcian blue), menunjukan bahwa ikan wader telah mengalami proses osifikasi atau penulangan sehingga pada hasil pengamatan dilihat hampir seluruh tulang ikan wader terwarnai merah yang berarti tersusun atas tulang keras. Sedangkan bagian kecil pada bagian ekor ikan terdapat warna biru yang menunjukan bahwa bagian tersebut tersusun atas tulang rawan.

2. Ekor ikan wader yang telah dipotong utuh siripnya kembali tumbuh mulai hari ke 6 secara perlahan hingga hari ke 21 telah kembali seperti semula.Pada pengamatan ini menunjukan bahwa pada bagian ekor ikan wader terdapat stem sel sehingga ekor ikan dapat mengalami regenerasi.

\section{Saran}

1. Pada proses pewarnaan ARAB perendaman yang terlalu lama pada $\mathrm{KOH}$ dapat mengakibatkan otot ikan menjadi sangat lunak dan terkelupas. Maka penggunaan waktu perendaman harus tepat dan mengikuti prosedur yang ada dengan lebih baik.
2. Hasil penemuan regenerasi ekor ikan ini bisa diaplikasikan pada makluk hidup yang lainnya karena pada dasarnya semua makhluk hidup memeiliki stem sel namun dalam penerapannya masih membutuhkan penelitian yang lebih mendalam lagi.

\section{Daftar Pustaka}

Ahmad Muchtar, Nofrizal, 2011. Pemijahan dan Penjinakan Ikan Pantau (Rasbora latestriata). Jurnal Perikanan dan Kelautan 16,1 (2011): 71-78. Universitas Riau.

Dasumiati. 2008. Diktat Kuliah Mikroteknik. Prodi Biologi Fakultas Sains dan Teknologi UIN Syarif Hidayatullah. Jakarta : UIN Syarif Hidayatullah Press.

Effendie, M. I. 1997. Biologi Perikanan. Yayasan Pustaka Nusatama. Yogyakarta.

Ersa, I.M. 2008. Gambaran Histopatologi Insang, Usus Dan Otot Pada Ikan Mujair (Oreochromis mossambicus) Di Daerah Ciampea Bogor. Skripsi. Fakultas Kedokteran Hewan Institut Pertanian Bogor. Bogor.

Gunarso W. 1986. Pengaruh Dua Jenis Cairan Fiksatif yang Berbeda pada Pembuatan Preparat dari Jaringan Hewan Dalam Metoda Mikroteknik Parafin. Bogor: IPB Press.

Kholish, Mahyuddin. 200. Panduan Lengkap Agribisnis Lele. Jakarta : Penebar Swaday.

Kottelat, M., A.J. Whitten, S.N. Kartikasari and S. Wirjoatmodjo. 1993. Freshwater Fishes of Western Indonesia and Sulawesi. PeriplusEMDI, Hongkong. 289p.

Kurniawan, Wahyu. 2010. Pembuatan Sediaan Irisan Jaringan Hewan Dengan Metode Parafin. Banjarbaru: Universitas Lambung Mangkurat. 
NN.Telaah

Pustaka.

http://bio.unsoed.ac.id/sites/default/files/B 1J010034-10.pdf.Universitas Jendral Sudirman. purwekerto.

Rahmadiyanto, Cahyo. 1994. Inventarisasi Ikan Di Sungai Brantas Kotamadya Malang. Skripsi tidak diterbitkan. Malang: IKIP Malang.

Sentosa Agus. 2010. Jurnal Iktiologi Indonesia, 10 (1): 55-63, 2010: Habitat Pemijahan Ikan Wader Pari (Rasbora lateristriata) di sungai Ngrancah Kabupaten Kulon Progo. Jurusan Perikanan Fakultas Pertanian Universitas Gajah Mada. Yogyakarta.

Sterba, G. 1989. Freshwater Fishes of The World. Volume I. Falcon Books, New Delhi. 